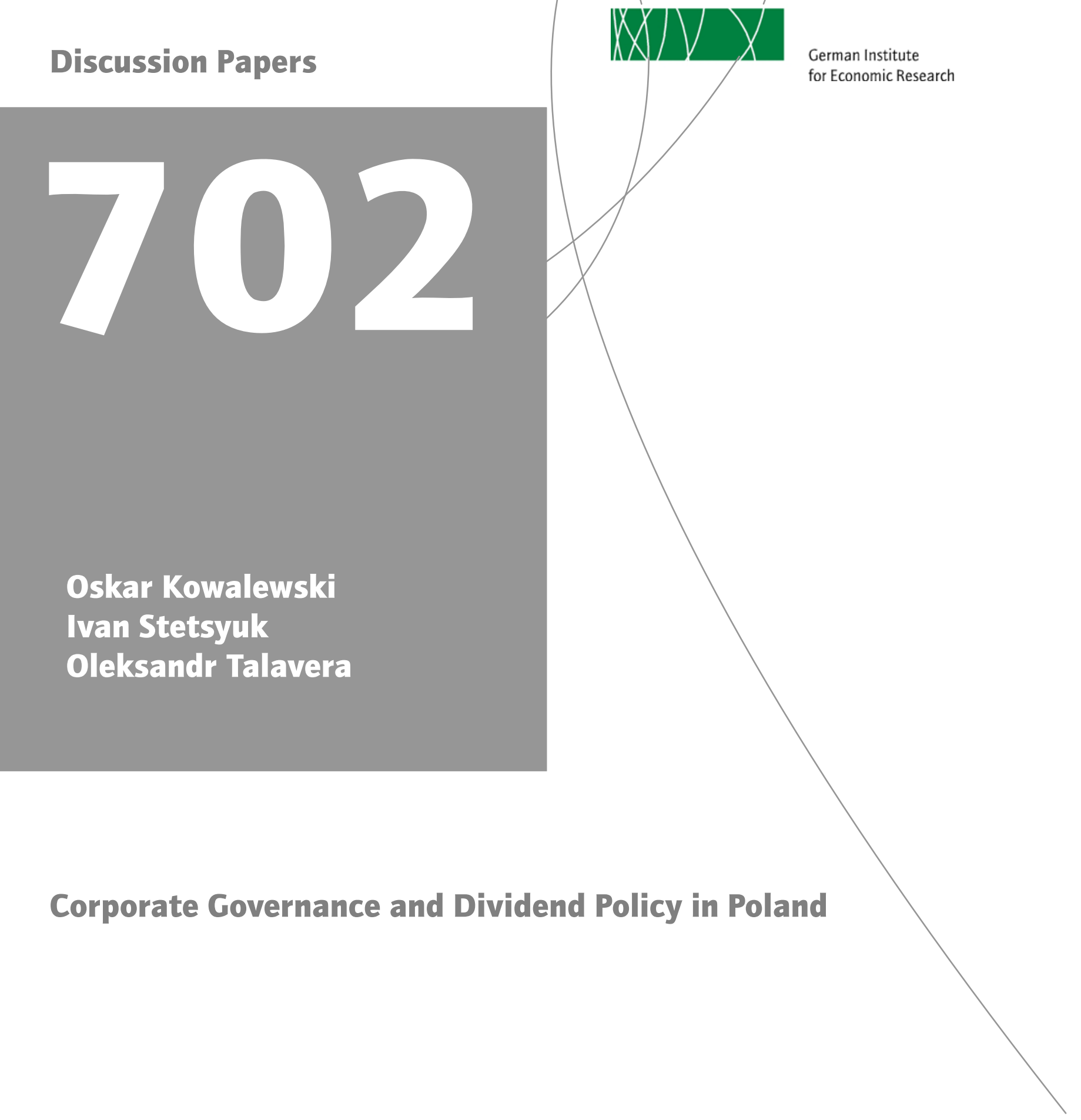

Berlin, July 2007 
Opinions expressed in this paper are those of the author and do not necessarily reflect views of the institute.

\section{IMPRESSUM}

(C) DIW Berlin, 2007

DIW Berlin

German Institute for Economic Research

Mohrenstr. 58

10117 Berlin

Tel. +49 (30) $89789-0$

Fax +49 (30) $89789-200$

http://www.diw.de

ISSN print edition 1433-0210

ISSN electronic edition 1619-4535

Available for free downloading from the DIW Berlin website. 


\title{
Corporate Governance and Dividend Policy in Poland
}

\author{
Oskar Kowalewski* \\ Warsaw School of Economics \\ Ivan Stetsyuk \\ UMCS \\ Oleksandr Talavera \\ DIW Berlin
}

\begin{abstract}
This study examines the relation between corporate governance practices measured by Transparency Disclosure Index (TDI) and dividend policy in Poland. Our empirical approach constructs measures of the quality of the corporate governance for 110 non-financial companies listed on Warsaw Stock Exchange between 1998 and 2004. We find evidence that an increase in the TDI or its subindices leads to an increase in the dividend-to-cash-flow ratio. These results support the hypothesis that companies with weak shareholder rights pay dividends less generously than do firms with high corporate governance standards. Therefore, minority shareholders often use power to extract dividends. We also find that large and more profitable companies have a higher dividend payout ratio, while riskier and more indebted firms prefer to pay lower dividends.
\end{abstract}

Keywords: corporate governance, dividend policy, agency theory JEL Classification Codes: G30, G32, G35

\footnotetext{
* Corresponding author: Warsaw School of Economics, World Economy Research Institute, Al. Niepodleglosci 162, 02554 Warsaw, Poland, Phone +48 (22) 56493 71, Fax +48 (22) 56493 74, e-mail: oskar.kowalewski@sgh.waw.pl
} 



\section{Introduction}

The existing empirical literature often finds statistically controversial effects of corporate governance on firm performance and dividend policy in developed countries (Gompers et al., 2003). In contrast, transition economies may offer more fertile ground for study, because they often have weaker rules and wider variations among firms in corporate governance practices (Mallin, 2000). The aim of the paper is to study whether companies' corporate governance practices are related to its dividend policies in a transition country. The literature suggests that corporate governance structures may be related to dividend policy. La Porta et al. (2000) state that firms located in countries with higher legal protection (common law system) to minority shareholders pay higher dividends, compared to countries where legal protection is weak (civil law system). In our opinion Poland with a civil law system offers an interesting setting as an economy in transition that has recently entered the EU, for which the dividend determinants still remain scarcely investigated. A study on the determinants of dividend policy and its association to corporate governance in a transition economy both offers an interesting subject and complements the existing corporate governance literature.

There has been considerable research that seeks to identify the determinants of corporate dividend policy. One line of this research has focused on an agency related rationale for paying dividends. It is based on the idea that dividends may mitigate agency costs by distributing free cash flows that otherwise would be spent on unprofitable projects (Jensen, 1986). Dividends expose firms to more frequent inspections by the capital markets as dividend payout increase the likelihood of new common stock issue (Easterbrook, 1984). However, this scrutiny helps alleviate opportunistic management behavior and thus agency costs, which, in turn, are related to the strength of shareholder rights and corporate governance (Gompers et al., 2003). In addition, shareholders may prefer dividends, particularly when they fear expropriation by insiders. As a consequence, we hypothesize that dividend payouts are determined by the strength of corporate governance. 
In order to measure corporate governance standards, we construct the Transparency Disclosure Index (TDI) for listed companies in Poland. The TDI most accurately reflects corporate governance policies in Polish companies that differ from the policies in the developed countries as well as from the practices in emerging economies. The construction of the sub-indices allows us to study particular corporate practices in depth. Our results suggest a positive and significant association between dividend payouts and corporate governance practices, indicating that firms pay higher dividends if shareholder rights are better protected. These results support the hypothesis that in companies providing strong minority shareholder rights, the power is often used to extract dividends. Hence, companies with weak shareholder rights pay dividends less generously than do firms with high corporate governance standards.

The reminder of this paper is organized as follows. The next section reviews some previous studies on corporate governance and dividend policy. Afterwards we examine the situation of corporate governance in Poland. Data discussion is then presented, followed by empirical results and robustness checks. The conclusions are given in the final section.

\section{The Literature on Corporate Governance and Dividend Policies}

In a pioneering effort, Black (1976) finds no convincing explanation of why companies pay cash dividends to their shareholders. Since that introduction of the "dividend puzzle," a voluminous amount of research offers alternative and appealing approaches to solve it. Most of them are rooted in information asymmetries between firm insiders and outsiders, and suggest that firms may indicate their future profitability by paying dividends. Grossman and Hart (1980) point out that the dividend payouts mitigate agency conflicts by reducing the amount of free cash flow available to managers, who do not necessarily act in the best interest of shareholders. Similarly, Jensen (1986) argues that a company with substantial free cash flows is inclined to adopt investment projects with negative net present values. If managers increase the amount of dividends, ceteris paribus, they also 
reduce the amount of free cash flows, and mitigate the free cash flow problem. Thus, dividend payouts may help control agency problems by getting rid of the excess cash that otherwise could be spent on unprofitable projects.

The importance of monitoring by investment banks has been recognized in literature. Shleifer and Vishny (1986) and Allen et al. (2000) note that institutional investors prefer to own shares of firms making regular dividend payments, and argue that large institutional investors are more willing and able to monitor corporate management than are smaller and diffuse owners. As a result, corporate dividend policies can be tailored to attract institutional investors, who in turn may introduce corporate governance practices.

La Porta et al. (2002) outline and test two agency models of dividends. First, the outcome model suggests that dividends are paid because minority shareholders pressure corporate insiders to disgorge cash. Second, the substitution model predicts that firms with weak shareholder rights need to establish a reputation for not exploiting shareholders. Hence, these companies pay dividends more generously than do firms with strong shareholder rights. In other words, dividends substitute for minority shareholder rights. The empirical results of La Porta et al. (2000) on a cross section study of 4,000 companies from 33 countries with different levels of minority shareholder rights support the outcome agency model of dividends. Accordingly, it is reasonable that outside minority shareholders prefer dividends over retained earnings. In line with that Bebczuk (2005) states that the testable prediction of this theoretical body is that dividend disbursements will be the higher the better are the corporate governance practices in the company. In this case corporate governance reflects the power of minority shareholders in the company.

The severity of agency costs is likely to be inversely related to the strength of shareholder rights (Gompers et al., 2003). Companies exposed to agency conflicts are more likely to experience a wider divergence of ownership and control, where shareholder rights are more suppressed. The shareholder rights are related to agency problems and thus also to dividend payouts. Therefore, in 
our paper we hypothesize that dividend policy is influenced by the strength of shareholder rights. In our opinion, the relationship should be especially strong in Poland, a country in transition, where the agency conflicts are strong and the shareholder rights are weak.

To capture the characteristics of the specific countries and their markets, it is of primary importance to construct separate transparency indices. For instance, Black et al. (2006a) use unique features of Korea's corporate governance rules to construct the governance index, while Hussain and Mallin (2003) employ a survey methodology to elicit information on corporate governance practice in Bahrain.

In order to estimate the influence of particular governance practices on the amount of dividends more accurately, it is necessary to construct a corporate governance measure consisting of several sub-indices. Our empirical strategy follows Bebczuk (2005), who splits the general index of TDI into several sub-indices and constructs the TDI using public information on 65 non-financial public Argentinean companies, reflecting their norms of transparency. His results point to a positive effect of the TDI on the amount of dividends, which disappears after controlling for size and Tobin’s q. In contrast to Bebczuk (2005), the Polish data shows that corporate governance measures are statistically significant even after controlling for plausible firm specific characteristics. Thus, our results reveal an existing difference in the impact of corporate governance on dividend policy between an emerging country from South America and a Central European transition country.

\section{Corporate Governance in Poland}

The Warsaw Stock Exchange (WSE) was established in 1817, but it was closed for more than fifty years due to the Second World War and the introduction of the centrally planned economy thereafter. The WSE reopened in 1991 with the first listed companies being four former stateowned firms. Since that time, the market developed gradually through privatization and the initial public offerings (IPOs) of former state-owned companies. The number of public companies with 
large market capitalization increased and the number of listings exceeded 200 in 1999. Therefore the Polish stock market is dominated by large privatized companies. As the privatization was almost complete, small and medium sized young private companies began to dominate at the IPO market recently.

The stock markets in Central Europe leaped into existence before the institutional infrastructure was established (Bonin and Wachtel, 2003). As a consequence, the equity listings often did not guarantee a transparent share registration, the ability to transfer ownership or the absence of manipulation of prices. To make things worse, the market regulations neither required any minimum standards of financial disclosure for firms nor promoted competitive activity (Judge and Naoumova, 2004). Hence, during the transition period corporate governance standards were very weak.

Following other stock exchanges in the region the WSE started the implementation of corporate governance principles in 2001. At first, a Best Practices Committee, consisting of government and industry representatives, was set up with the aim to create the Best Practice Code for listed companies. The first Code was presented in the autumn of 2002 and, since then, all listed companies could declare if they were going to follow all or just selected rules of the Code. The Code was reviewed and amended by the Committee twice. The modifications of the Code were made based on the practical experience and recommendations of the European Commission. As of August 2006, the declaration on best practiced rules of 2005 was filled by 263 of 268 listed companies on the WSE. However, many of those companies that filled the declaration often ignored the procedure of the appointment of independent directors in the board of directors. Thus, the Code presents only a weak implementation of corporate governance standards in Poland.

The development of the stock exchange and the growing share of foreign investors enhanced the improvement of the corporate governance standards. Allen et al. (2006) suggest in a study on financial development in the EU-25 that introduction of securities laws on the books is remarkable 
in Central Europe. Using an index they report that the level of investor protection and securities markets regulations is comparable to the "old" EU member countries. Thereby, corporate governance standards have improved in Poland and it may have an impact on the protection of minority shareholders and the dividend payout of listed companies (Koladkiewicz, 2001).

Special consideration of the protection of shareholder rights is advocated by various institutions such as World Bank and Polish Forum for Corporate Governance (PFCG) that has conducted research in the field. The PFCG highlights that Poland has still to implement some of the solutions that would safeguard sufficient protection of shareholders. Among the solutions are the legal devices that should protect minority interests, improve supervisory board and management functioning, and raise corporate transparency. Additionally, World Bank Report on the Observance of Standards and Codes (2005) highlights that the major weakness of corporate governance practices in Poland is the lack of rules on the approval of related party transactions. The report mentions several cases to indicate that minority shareholders may be at risk in companies controlled by foreign strategic shareholders, which are interested in pushing down the price in order to take private the company cheaply. This accusation is especially powerful as in the last decade the majority of going private transactions has been executed by foreign investors (Jackowicz and Kowalewski, 2006). A large number of going private transactions may also indicate the existence of a potential agency conflict between foreign investors and minority shareholders in Poland.

Additionally, with the lack of board independence, many companies are open to potential expropriation which, in turn, may create the necessary conditions for the dividend policies well explained by the outcome model. Ability to disgorge cash is detrimental to outside shareholders' interest, otherwise the excess funds might be diverted or wasted. Taking into account both the literature on dividend policies and current situation with the dividends in Poland, we formulate the following hypothesis: corporate governance practices have a significant impact on the amount of dividends paid out to shareholders in Poland. 


\section{Data description}

The financial data comes from the ISI Emerging Market database and the annual reports of the companies listed on the WSE. The statistics for the corporate governance index comes from annual reports, filings with domestic regulatory agencies, and companies' websites. The data collection for the corporate governance index was completed between August and November 2005. We are initially reporting information on corporate governance index on the total 155 listed companies as of November 2005. The sample is later substantially reduced because we exclude the companies with missing performance or control variables. The final data set for the panel regressions consists of 110 listed companies during 1998-2004. In addition, we construct two subsamples (1998- 2001 and 2002-2003 sub-periods) to control for the rapid decline of the stock markets around the world as well as the economic slowdown in Poland at the end of 2001.

To test the empirical hypothesis we need appropriate indicators for dividend measure. Following the corporate finance literature, we apply the ratio of cash dividends to cash flows as the main dividend measure (Faccio et al., 2001). As cash flow is the relevant measure of company’s disposable income this ratio captures the choice to distribute the money generated each year to shareholders or not.

The return on assets (ROA) and Tobin's q are our main explanatory variables. The former is included as an accounting measure that is beyond management manipulation and is calculated as the earnings before interest and taxes over total assets. The ratio reflects the availability of resources to distribute once investment funding is secured, which increases dividend payments. The latter proxy reflects expectations about future earnings and market perceptions about the value of the company. Companies' demand of funds for further investments is represented by a high Tobin's q value, which should have a negative impact on dividends. Following the tradition of the dividend policy literature, we also include size and leverage. We anticipate that firm size has a positive effect on the dividend payout of a firm. As a rule, large firms are well diversified, and their further growth 
opportunities are often exhausted. The ratio of long term debt to assets is employed as a measure of firm's leverage and closeness to debt covenant restrictions. High leverage and the implied financial risk should be associated with lower dividend payout as it discourages both paying out dividends and taking further loans.

Following Black et al. (2006b) and Bebczuk (2005), we employ the TDI to gauge the strength of corporate governance practices in listed companies in Poland. The TDI is based on public information and reflects the norms of transparency and disclosure in a company. The TDI comprises of 32 binary items presented in Table 1, which cover a broad range of corporate governance topics. The binary item equals one if a company follows one of the corporate governance standards and zero otherwise. The TDI consists of three subindices: Board, Disclosure and Shareholders. The subindex Board measures the structure, procedures and compensation of board and top management members. The subindex Disclosure measures the degree to which the company informs relevant corporate facts to outside stakeholders. The last subindex Shareholders measures the quality of information regarding the compensation to minority shareholders. Table 1 shows the percentage of positive entries for the TDI and its three subindices.

\section{[Insert Table 1 about here]}

The econometric specifications also include industry and time dummies. Taking into account the importance of industry effects on companies' performance, firms are classified into three broad sectors: industry, services and primary products. They all vary in productive technology and international tradability.

\section{Empirical Implementation}

Our research strategy is based on identifying fundamental determinants that explain cash dividends to cash flow ratios' in relation with our corporate governance measures. We estimate pooled Tobit regression model similar to the study of Bebczuk (2005). This empirical methodology 
is applied as the dependent variable is truncated at zero and it has numerous individual observations displaying such value in our sample. Our sample consists of 110 non-financial publicly listed companies with 760 observations over 1998-2004. It is also divided into two sub-samples: 19982001 and 2002-2004.

The descriptive statistics for our corporate governance measures are presented in Panel A of Table 2. The mean of TDI (0.41) illustrates that the corporate governance standards are on average relatively low in the listed companies. Two of the three subindices of the TDI are surprisingly low. The subindex Shareholders is quite low at 0.35 , and the subindex Board is even lower with a value of 0.32. The subindex Disclosure, with a value of 0.51 , is the highest among the three subindices. The subindices present large variation in corporate governance standards across listed companies in our sample. The high value of the TDI subindex Disclosure reflects good corporate governance practices in informing the shareholder, and the low value of the two other subindices indicate relatively low standards regarding management, board and minority shareholders protection.

Panel B of Table 2 shows that the average firm in our sample has corporate assets of 626 million PLN (\$210 million). The mean dividend payout ratio to cash flow is 0.05. Also, the dividends to earnings and dividends to sales present a large variation across companies. The mean value for this payout ratios are 0.1 and 0.01 , respectively. Most listed companies in our sample are from the industry sector, followed by service sector, while firms from the primary industry sector are the least present.

\section{[Insert Table 2 about here]}

We split our sample of listed companies into dividend payers and non-dividend payers to test whether means are different. Table 3 reports the mean value of the main variable of interests for dividend payers and non-dividend payers firms. The comparison supports our hypothesis on association of dividend policy and corporate governance. Dividend-paying companies are on average larger, more profitable and less levered than non-dividend-paying. The average difference 
between dividend payers and non-dividend payers companies is significantly different at 1 per cent level.

Panel B of Table 3 presents that dividend-paying companies have better corporate governance as estimated by the TDI and its subindices. The results are significant at 1 per cent confidence level and present the expected differences across listed companies in our sample. The considerable differences in the variables support our assumption that financial determinants as well as corporate governance standards may have an impact on the dividend policy of a company. Differences in means are statistically significant for all the variables, except Tobin's q, yet this variable should be negatively associated with dividend payout ratio.

\section{[Insert Table 3 about here]}

We test the association of corporate governance with dividend policy in a multiple regression framework to control for firm specific characteristics other than governance. The results of a regression analysis for pooled Tobit are shown in Table 4. We regress dividend payout to cash flow ratio against the TDI. The governance index captures the impact of the strength of shareholder rights on dividend policy. We also add our set of control variables that determine the dividend policy, showing the results with a partial set of control variables in specifications (2)-(5).

The TDI is highly significant in each of these regressions. Adding control variables does not change significantly the coefficient of the TDI. Regression (1) implies that an increase in corporate governance index by one point results in an increase of dividend-to-cash flow by 0.91 points. The regressions (2)-(5) present a worst-to-best change in the TDI from 0.69 to 1.02. Size and return on assets are positively associated with the variable cash dividends to cash flow at 1 per cent significance level. Leverage is negatively associated with the variable cash dividends to cash flow at 1 per cent significance level but Tobin's q variable is not statistically significant. The dummy variables are included only to control for potential industry and year effects. Sectors' dummies 
variables are statistically significant in four regression models. Nonetheless, primary products sector dummy never enters the specification significantly.

\section{[Insert Table 4 about here]}

In addition, we regress dividend-to-cash flow on the TDI and the three subindices that comprise the index: Board, Disclosure and Shareholders. The results of pooled Tobit regression for the whole period 1998-2004 and the two subperiods 1998-2001 and 2002-2004 are shown in Table 5. All the regressions include time and sector dummies.

In all the regressions the TDI and each individual TDI subindex is statistically significant. The strongest results are for the TDI subindices Board, Disclosure and Shareholder, in that order. The coefficient of 0.86 on subindex TDI Disclosure, for example, implies that the improvement in corporate governance practice concerning disclosure in the years 1998-2004 by 1 point predicts a 0.86 points increase of dividends-to-cash flow ratio. Our results show significant differences in results between two subperiods. We observe that the relationship has sizeable effects for both subperiods: for the first from 1998 to 2001 and for the second from 2002 to 2004. The TDI of corporate governance measure is a valid measure of minority shareholder protection and thus also dividend payout ratio in throughout our sample period. Its prediction power is not getting weaker because of the implementation of corporate standards across listed companies in Poland. The TDI remain statistically significant at 1 per cent or 5 per cent level and thus the results present a strong correlation between dividend payout and companies' corporate governance. This implies that the elements of the corporate governance index have more predictive power when aggregated into an index than individually.

\section{[Insert Table 5 about here]}

\section{Sensitivity Analysis}

We next conduct a number of robustness tests. We test the sensitivity of the results to a number of alternative specifications of our regression ${ }^{1}$. First, we check the consistency of the results 
after removing outliers. These outliers are eliminated after considering the scatter plot of the dividend payout regressions involving corporate governance measure. We eliminate those companies that fall particularly far from the regression line and then repeat the estimation on the new sample. After dropping out the extreme observations we still get a significant and positive relationship between corporate governance practice and dividend payout.

Second, there are not many ways of measuring the variables that enter the regression. Nevertheless, as we want to ensure that the results are not due to our choice of indicators, we perform a number of robustness tests using alternative measures for dividend payout and corporate governance practice. We repeat the regressions reported in this paper using an alternative measure for the dividend payout ratio. The new ratio was defined as dividends to earnings or dividends to sales. In both cases, the pooled Tobit results are qualitatively the same as those previously reported. The TDI and its subindices were significantly and positively associated with the alternative dividend payout ratios.

We also run a regression using an alternative index for corporate governance practice. We employed the Polish Corporate Governance Rating for 50 listed companies instead of the TDI. The coefficient was still positive, yet the results were weaker. As an alternative index for corporate governance practice we have also employed a variable, which reflects the number of rules followed by the listed companies from the WSE Best Practice Code. In this case the coefficient was relatively small and not statistically significant. Therefore, in our opinion, the Best Practice Code may not be used as a proxy for corporate governance practice. We also compute the regressions changing ratios for both the dependent variable and the main regressor, using the Polish Corporate Governance Rating, and in either case the signs of the estimated coefficients have not changed.

Finally, changing the conditioning information set has not affected our results. Further increasing the set of explanatory variables included in the regressions with the sales' growth, company's age and dummy variables for foreign ownership or for GDRs, does not change either the 
significance level or the sign of the estimated coefficients. Concluding, the results of the sensitivity test using a different set of data remain unaffected by an array of robustness checks and confirm our previous finding on the link between corporate governance practice and dividend payout.

\section{Conclusions}

Our empirical results demonstrate that corporate governance is an important determinant in explaining the dividend policy of listed companies in Poland. To measure the quality of corporate governance, we construct the Transparency Disclosure Index for 110 companies listed on the WSE. In line with our predictions, and controlling for other factors, we find strong positive correlation between the overall TDI and dividend payout, which is robust across different regression specifications and time subsamples. Our measure for corporate governance, the TDI, and its subindices enter positively and significantly the regressions. For the whole period 1998-2004, one point increase of the TDI, the subindex of Board, the subindex Disclosure, the subindex Shareholders brings about an increase of 45.32, 26.93, 36.93, and 21.41 points respectively in the dividend-to-cash flow ratio.

Our results for the remaining potential dividend determinants are in line with the corporate finance literature and expectations. We find that larger companies by asset size and more profitable firms without good investment opportunities pay more dividends. Furthermore, riskier and more indebted firms prefer to pay lower dividends.

Concluding, our results provide evidence that listed companies in Poland where corporate governance practice are high and as a consequence shareholder rights are strong payout higher dividends. Those results are in line with the outcome model assuming that when shareholders have greater rights, they can use their power to influence dividend policy. This study contributes to the literature both in dividend policy and in agency theory. In dividend policy, we show that corporate governance is a significant determinant of dividend policy in transition countries. In agency theory, 
this study presents that in companies with strong corporate governance standards the agency conflict may be mitigated as the free cash flow may be utilized rather as dividend than an investment with a negative net present value. 


\section{References}

Allen, F., Bernardo, A. and Welch, I. (2000) A Theory of Dividends Based on Tax Clienteles, Journal of Finance, 55, 2499-2536.

Allen, F., Bartiloro, L. and Kowalewski, O. (2006) The Financial System of the EU 25. In Liebscher, K., Christl, J. and Mooslechner, P. (eds.), Financial Development, Integration and Stability in Central, Eastern and South-Eastern Europe. Cheltenham: Edward Elgar.

Bebczuk, R. (2005) Corporate Governance and Ownership: Measurement and Impact on Corporate Performance and Dividend Policies in Argentina, Center for Financial Stability, Working Paper.

Black, F. (1976) The Dividend Puzzle, Journal of Portfolio Management, 2, 5-8.

Black, B., Jang, H. and Kim, W. (2006a) Does Corporate Governance Predict Firms' Market Values?: Evidence from Korea, Journal of Law, Economics and Organization, 22 (2), 366-413.

Black, B., Jang, H. and Kim, W. (2006b) Predicting Firms' Corporate Governance Choices: Evidence from Korea, Journal of Corporate Finance, 12 (3), 660-691.

Bonin, J. and Wachtel, P. (2003) Financial Sector Development in Transition Economies: Lessons from the First Decade, Financial Markets, Institutions and Instruments, 12 (1), 1-66.

Easterbrook, F. H. (1984) Two Agency-Cost Explanations of Dividends, American Economic Review, 74, 650-659.

Faccio, M., Lang, L. and Young, L. (2001) Dividends and Expropriation, American Economic Review, 91 (1), 54-78.

Gompers, P., Ishii, J. L. and Metrick, A. (2003) Corporate Governance and Equity Prices, Quarterly Journal of Economics, 118, 107-155.

Grossman, S. and Hart, O. (1980) Disclosure Laws and Take-over Bids, Journal of Finance, 35, 323-334.

Hussain, S. H. and Mallin, C. (2003) The Dynamics of Corporate Governance in Bahrain: Structure, Responsibilities and Operation of Corporate Boards, Corporate Governance: An International Review, 11, 249-261.

Jackowicz, K. and Kowalewski, O. (2006) Why Do Companies Go Private in Emerging Markets? Evidence from Poland, The Journal for East European Management Studies, 11(4), 328 - 350. 
Jensen, M. (1986) Agency Costs of Free Cash Flow, Corporate Finance, and Takeovers, American Economic Review, 76, 323-329.

Johnson, S. H., La Porta, R., Lopez-de-Silanes, F. and Shleifer, A. (2000) Tunnelling, NBER Working Paper No. W7523.

Judge, W. and Naoumova, I. (2004) Corporate Governance in Russia: What Model Will It Follow? Corporate Governance: An International Review 12 (3), 302-313.

Koladkiewicz, I. (2001) Building of a Corporate Governance System in Poland: Initial Experiences Corporate Governance: An International Review, 9 (3), 228-237.

La Porta, R., Lopez-de-Silanes, F., Shleifer, A. and Vishny, R. (2000) Investor Protection and Corporate Governance, Journal of Financial Economics, 58 (1-2), 3-27.

La Porta, R., Lopez-de-Silanes, F., Shleifer, A., and Vishny, R. (2002) Agency Problems and Dividend Policies Around the World, Journal of Finance, 55 (1), 1-33.

Mallin C., (2000) Developments in Corporate Governance in Central and Eastern Europe, Corporate Governance: An International Review, 8 (1), 43-51.

Shleifer, A., Vishny R. (1986) Large Shareholders and Corporate Control, Journal of Political Economy, 94, 461-488.

\footnotetext{
${ }^{1}$ The results of robustness analysis are not reported but are available upon request.
} 
Table 1

\section{Structure of the Transparency and Disclosure Index (TDI)}

The TDI measures a broad set of corporate governance features for 154 listed firms in Poland using public information in August 2005 to November 2005. Public sources include annual reports, filings with national regulators, internet sources, and business publications. For each feature, the company is given a value 1 if there is partial or total public information and 0 otherwise. The subindex Board measures the structure, procedures and compensation of Board and Top Management members. The subindex Disclosure measures the degree to which the company informs relevant corporate facts to outside stakeholders. Finally, the subindex Shareholders measures the quality of information regarding the compensation to minority shareholders

\begin{tabular}{|c|c|}
\hline Item & $\begin{array}{c}\% \text { of firms with public } \\
\text { information on each item }\end{array}$ \\
\hline \multicolumn{2}{|l|}{ A. Board structure and procedures (TDI-Board) } \\
\hline Independency criteria for directors & 22.08 \\
\hline Years in office of present Directors & 23.38 \\
\hline Code of Conduct for Directors & 74.68 \\
\hline Manager and director fees & 70.78 \\
\hline Form of manager and director fee payment (cash, stock, stock options) & 51.30 \\
\hline Rationale of manager and director fees & 34.42 \\
\hline Information on whether manager and director fees are performance-based & 38.96 \\
\hline Shareholdings of managers and directors & 74.03 \\
\hline Number and percentage of independent directors & 24.68 \\
\hline Details on the nomination process of new directors & 1.30 \\
\hline Report on issues by dissident directors & 0.00 \\
\hline Composition of the different Board committees & 6.49 \\
\hline Details on activities of the different Board committees & 1.30 \\
\hline \multicolumn{2}{|l|}{ B. Disclosure (TDI-Disclosure) } \\
\hline Bio of main company officers & 34.42 \\
\hline Bio of Directors & 27.92 \\
\hline Calendar of future events & 41.56 \\
\hline English-translated corporate website & 85.71 \\
\hline Financial indicators for the last 5 years & 81.82 \\
\hline Strategic plan and projections for the following years & 29.87 \\
\hline Publication of Board meeting resolutions & 94.16 \\
\hline Publication of shareholders meeting resolutions & 94.81 \\
\hline Details on the appointment process of new directors & 0.65 \\
\hline $\begin{array}{l}\text { Details on attendance of minority and controlling shareholders in } \\
\text { shareholders' meetings }\end{array}$ & 1.30 \\
\hline Reports on issues raised by dissident shareholders & 0.00 \\
\hline Year of hiring of the external auditor & 97.40 \\
\hline Report of the external auditor & 97.40 \\
\hline \multicolumn{2}{|l|}{ C. Shareholders (TDI-Shareholders) } \\
\hline Details of corporate ownership (principal shareholders) & 94.81 \\
\hline Type and amount of outstanding shares & 89.61 \\
\hline Document on internal corporate governance standards & 1.30 \\
\hline Dividend policy in the past 5 years & 18.83 \\
\hline Projected dividend policy for the following years & 7.14 \\
\hline Rationale of the past and/or future dividend policy & 11.04 \\
\hline
\end{tabular}

Source: Own elaboration from public sources. 
Table 2

Descriptive Statistics

Table shows the mean, standard deviation, minimum and maximum values of the corporate governance index, performance and control variables, whose definitions are provided in Appendix.

Variable

Definitions

Mean

Std. Dev.

Panel A: Corporate Governance Index

\begin{tabular}{llll}
\hline TDI & Transparency and Disclosure Index & 0.406 & 0.134 \\
TDI- Board & Board structure and procedures & 0.322 & 0.189 \\
TDI- Disclosure & Disclosure & 0.513 & 0.152 \\
TDI- Shareholder & Shareholders & 0.355 & 0.159
\end{tabular}

Panel B: Performance and Control Variables

\begin{tabular}{|c|c|c|c|}
\hline ROA & Earnings before interest and taxes to total assets & 0.020 & 0.132 \\
\hline Tobin's q & $\begin{array}{l}\text { Market value of equity plus the book value of } \\
\text { liabilities to book value of assets }\end{array}$ & 1.417 & 2.420 \\
\hline Dividends to cash flow & $\begin{array}{l}\text { Cash dividends to total earnings plus } \\
\text { depreciation }\end{array}$ & 0.053 & 0.409 \\
\hline Dividends to earnings & Cash dividends to total earnings & 0.096 & 0.673 \\
\hline Dividends to sales & Cash dividends to sales & 0.014 & 0.166 \\
\hline Assets & The company's total assets & 625620 & 3038420 \\
\hline Debt to Assets & Total debt to assets & 0.517 & 0.389 \\
\hline Primary Dummy & $\begin{array}{l}\text { This variable takes the value } 1 \text { if the company } \\
\text { produces agricultural products, livestock, } \\
\text { minerals, or other commodities, and } 0 \text { otherwise. } \\
\text { The activity classification is taken from the NACE. }\end{array}$ & 0.164 & 0.370 \\
\hline Industry Dummy & $\begin{array}{l}\text { This variable takes the value } 1 \text { if the company } \\
\text { belongs to the industrial sector, and } 0 \text { otherwise. } \\
\text { The activity classification is taken from the NACE }\end{array}$ & 0.627 & 0.484 \\
\hline Services Dummy & $\begin{array}{l}\text { This variable takes the value } 1 \text { if the company } \\
\text { provides services or supplies utilities, and } 0 \\
\text { otherwise. The activity classification is taken from } \\
\text { the NACE. }\end{array}$ & 0.200 & 0.400 \\
\hline
\end{tabular}


Table 3

Mean difference tests

Table shows the means of the balance sheet variables used in the estimation and broken down into dividend payers and nondividend payers. The sample covers 110 companies over 1998- 2004.

\begin{tabular}{lcccc}
\hline \hline & $\begin{array}{c}\text { Mean } \\
\text { Non-Dividend } \\
\text { Payers }\end{array}$ & $\begin{array}{c}\text { Mean } \\
\text { Dividend Payers }\end{array}$ & Difference & P-value \\
\hline \hline Panel A: Balance Sheet Variables & & & \\
\hline Ln(Assets) & 11.600 & 12.061 & -0.462 & 0.000 \\
ROA & -0.004 & 0.073 & -0.076 & 0.000 \\
Tobin's q & 1.407 & 1.438 & -0.031 & 0.872 \\
Debt to assets & 0.584 & 0.365 & 0.220 & 0.000 \\
\hline & & & & \\
Panel B: TDI Indices & & & & \\
& 0.392 & 0.433 & -0.041 & 0.000 \\
\hline TDI & 0.309 & 0.351 & -0.042 & 0.005 \\
TDI-Board & 0.498 & 0.540 & -0.041 & 0.001 \\
TDI-Disclosure & 0.343 & 0.381 & -0.038 & 0.003 \\
TDI-Shareholders & & & & \\
\hline \hline
\end{tabular}


Table 4

\section{Cash Dividends to Cash Flow: TDI and Balance Sheet Determinants}

Pooled Tobit results for yearly data 1998-2004 and a maximum of 110 non-financial listed firms. The yearly cash dividends are those announced once the company's fiscal year has ended, and the accounting variables are calculated from such fiscal year's statements. Observations with percentage ROA smaller than -20 and higher than 20 are dropped. The TDI (on a 0-100 scale) is the same for all periods, and is based on public corporate information for 2005. For each regression the controls are time and sector dummies (not reported).

\begin{tabular}{lccccc}
\hline & 1 & 2 & 3 & 4 & 5 \\
\hline \hline Constant & $-0.890^{\star \star \star}$ & $-1.333^{\star \star \star}$ & $-1.081^{\star \star \star}$ & $-0.878^{\star \star \star}$ & $-0.277^{\star}$ \\
TDI & $(0.161)$ & $(0.321)$ & $(0.163)$ & $(0.161)$ & $(0.157)$ \\
& $0.907^{\star \star \star}$ & $0.685^{\star \star}$ & $0.689^{\star \star \star}$ & $0.928^{\star \star \star}$ & $1.015^{\star \star \star}$ \\
Ln(Assets) & $(0.243)$ & $(0.277)$ & $(0.233)$ & $(0.245)$ & $(0.237)$ \\
& & 0.045 & & & \\
ROA & & $(0.027)$ & & & \\
& & & $3.472^{\star \star \star}$ & & \\
Tobin's q & & $(0.464)$ & & \\
& & & 0.001 & \\
Debt to Assets & & & & & \\
& & & & & $-1.515^{\star \star \star}$ \\
Industry dummy & & & & & $0.180)$ \\
& & & & & \\
Primary product dummy & $0.281^{\star \star \star}$ & $0.298^{\star \star \star}$ & $0.293^{\star \star \star}$ & $0.278^{\star \star \star}$ & $(0.084)$ \\
& $(0.088)$ & $(0.090)$ & $(0.086)$ & $(0.088)$ & 0.004 \\
\hline Observations & 0.026 & 0.029 & 0.085 & 0.017 & $(0.113)$ \\
Chi2 & $(0.117)$ & $(0.118)$ & $(0.113)$ & $(0.117)$ & 765 \\
Obs. left-censored at & 765 & 765 & 765 & 757 & 137.238 \\
zero & 37.011 & 39.724 & 117.189 & 38.622 & 570 \\
\hline \hline
\end{tabular}

${ }^{*},{ }^{* *}$, and ${ }^{* * *}$ indicate significance at $10 \%, 5 \%$, and $1 \%$ levels.

$\mathrm{T}$ statistics based on robust standard errors in parenthesis 


\section{Table 5}

\section{Cash Dividends to Cash Flow and TDI}

Each line of Table displays, for the whole period (1998-2004) and two subperiods (1998-2001 and 20022004), the estimated coefficient (and robust t statistic) on alternative TDI measures, namely, the three subindices defined in the text (Board, Disclosure, Shareholders) - each measured, as the TDI, on a 0-100 scale, the principal component of these three subindices, and the median overall TDI. For each pooled Tobit regression, the controls are time and sector dummies.

\begin{tabular}{lccc}
\hline \hline & Tobit 1 & Tobit 2 & Tobit 3 \\
& $(1998-2004)$ & $(1998-2001)$ & $(2001-2004)$ \\
\hline \hline TDI & $0.907^{\star \star \star}$ & $0.781^{\star *}$ & $1.077^{\star \star \star}$ \\
TDI-Board & $(0.243)$ & $(0.304)$ & $(0.406)$ \\
& $0.458^{\star \star \star}$ & 0.276 & $0.741^{\star \star}$ \\
TDI-Disclosure & $(0.171)$ & $(0.211)$ & $(0.293)$ \\
& $0.855^{\star \star \star}$ & $0.996^{\star \star \star}$ & $0.639^{\star}$ \\
TDI-Shareholders & $(0.228)$ & $(0.297)$ & $(0.366)$ \\
& $0.471^{\star \star}$ & 0.340 & $0.672^{\star \star}$ \\
TDI-Principal component & $(0.199)$ & $(0.245)$ & $(0.341)$ \\
& $0.087^{\star \star \star}$ & $0.074^{\star *}$ & $0.106^{\star * \star}$ \\
TDI-Median & $(0.024)$ & $(0.030)$ & $(0.040)$ \\
& $0.270^{\star \star \star}$ & $0.228^{\star \star}$ & $0.328^{\star \star \star}$ \\
\hline \hline
\end{tabular}

$*$, **, and $* * *$ indicate significance at $10 \%, 5 \%$, and $1 \%$ levels.

T statistics based on robust standard errors in parenthesis 